Research Journal of Environmental and Earth Sciences 11(2): 19-28, 2019

DOI:10.19026/rjees.11.6025

ISSN: 2041-0484; e-ISSN: 2041-0492

(C) 2019 Maxwell Scientific Publication Corp.

Submitted: February 12, 2019

Accepted: March 27, 2019

Published: November 20, 2019

\title{
Research Article \\ Hydrochemistry and Groundwater Quality in a Quaternary Phreatic Qquifer in Yenagoa, Southern Nigeria
}

\author{
${ }^{1}$ E. Akpofure, ${ }^{2}$ K.S. Okiongbo and ${ }^{3}$ A.R.C. Amakiri \\ ${ }^{1}$ Department of Geology, Niger Delta University, Wilberforce Island, Bayelsa State, Nigeria \\ ${ }^{2}$ Geophysics Unit, Department of Physics, Niger Delta University, Wilberforce Island, Bayelsa State, \\ ${ }^{3}$ Department of Physics, Rivers State University, Port Harcourt, Rivers State, Nigeria
}

\begin{abstract}
Hydrochemical investigation of groundwater samples was carried out in Yenagoa, Southern Nigeria in an attempt to determine the suitability of the groundwater quality for domestic use. Twenty four groundwater samples were collected from domestic boreholes in the study area and were analyzed for major ions. The hydrochemical parameters determined were statistically examined and correlated. Factor analysis was applied to extract the principal factors responsible for the variation in the hydrochemistry. Water Quality Index (WQI) rating was calculated to quantify overall suitability of the water for human consumption. The results show that the correlation coefficient matrix between Electrical Conductivity (EC), $\mathrm{Na}^{+}$and $\mathrm{Cl}^{-}$was significant, which is an indication of seawater influence on the groundwater quality. The geochemistry of the groundwater is controlled mainly by rockwater interaction, ion exchange reactions, reductive dissolution of iron bearing minerals and weathering of silicate group of minerals. The WQI of the study area ranged from 5.7-32.7, indicating excellent water quality.
\end{abstract}

Keywords: Factor analysis, groundwater, hydrochemistry, water quality index, Yenagoa

\section{INTRODUCTION}

Yenagoa (the capital of Bayelsa State) in Southern Nigeria lacks municipal water supply, therefore groundwater has been the main source of water supply for over $95 \%$ of residents in the City and environs. The quality of groundwater for domestic use, industrial and irrigation purposes depends on its chemical and biological constituents (Singh and Singh, 2008), hence understanding the chemical composition of groundwater is necessary for evaluating its suitability for different purposes. Hydrochemical analysis of groundwater is important not only in determining the potability of groundwater in an area, but also enables the understanding of the geology and the movement of groundwater. A wide variety of dissolved inorganic chemical constituents are contained in groundwater. This is as a result of the hydrogeochemical processes that alter its chemical composition as it flows along its path from recharge to discharge areas. The type and concentration of these constituents depend upon several factors such as the composition of the precipitation, the kind of geological structure and mineralogy of the watersheds, aquifers and the geological processes that occur within the aquifer (Andre et al., 2005).
Despite the importance of groundwater in Yenagoa city and environs, there had been no detailed characterization of the groundwater quality. We remain remarkably ignorant of the natural phenomena that govern the chemical composition of groundwater in the area or the anthropogenic factors that influence the groundwater composition. Water quality is determined using different techniques. Some of the conventional methods used to determine water quality include hydrogeochemical methods (Amadi et al., 1989; AlTaani, 2012), geophysical investigations (El Kashony et al., 2012) and remote sensing with GIS (Ketara et al., 2012). Fuzzy complex logic and geostatistics are new innovations used in the assessment of water quality (Saji Kumar et al., 2011). On the otherhand, Water Quality Index (WQI) has proved to be an effective tool in determining the quality of groundwater, a technique that is based on a group of physico-chemical and biological characteristics of the water samples. Generally, a single number, "index", obtained from a large number of variables (Sanchez et al., 2007) can be used to represent the water quality level. The present study was carried out in an attempt to evaluate the groundwater chemistry and quality in the study area.

Corresponding Author: K.S. Okiongbo, Geophysics Unit, Department of Physics, Niger Delta University, Wilberforce Island, Bayelsa State, Nigeria

This work is licensed under a Creative Commons Attribution 4.0 International License (URL: http://creativecommons.org/licenses/by/4.0/). 


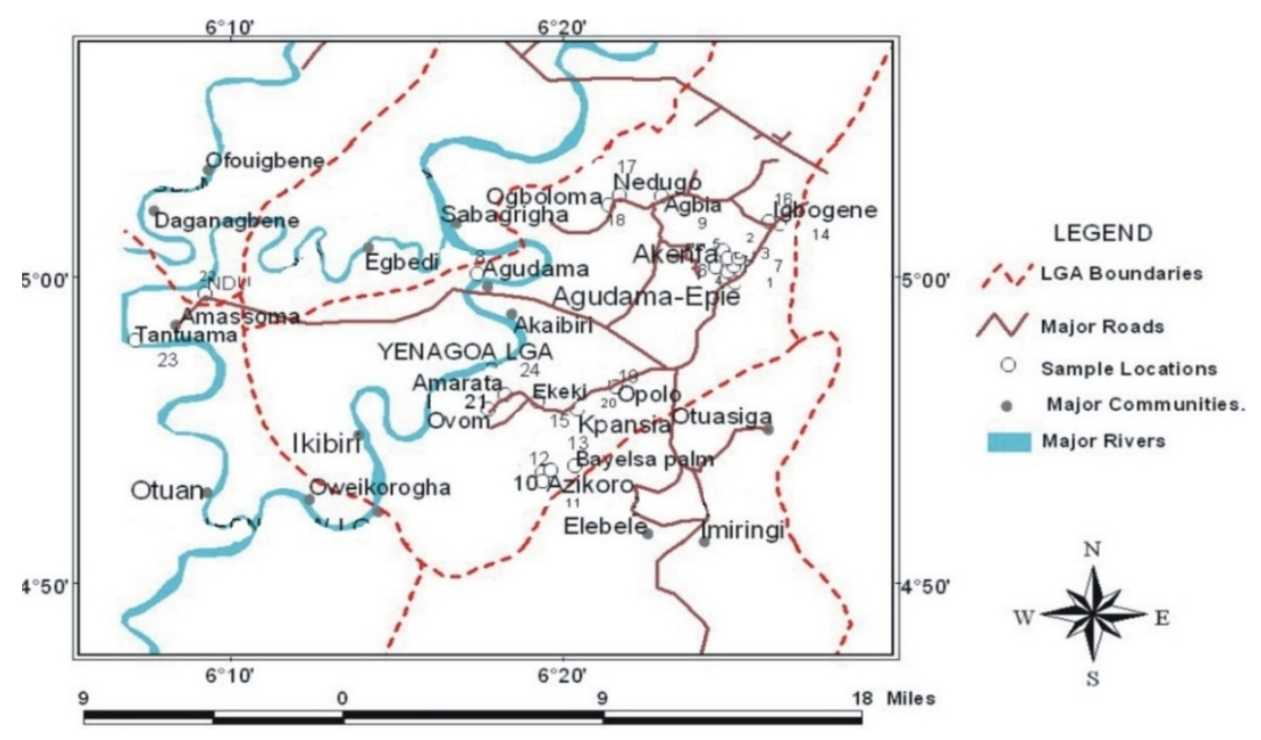

Fig. 1: Map of study area showing sample locations

Geology of the study area: The study area lies between longitudes $006^{\circ} 05^{\prime}$ and $006^{\circ} 025^{\prime}$ East of the prime meridian and latitudes $04^{\circ} 23.3^{\prime}$ and $04^{\circ} 38.2^{\prime}$ North of the equator within the coastal area of the recent Niger Delta in Southern Nigeria (Fig. 1). The study area is about $100 \mathrm{~km}^{2}$ and is located within the tropical equatorial climate region with a temperature range of $23-38^{\circ} \mathrm{C}$. Generally the topography of the area is gentle and elevation is below $50 \mathrm{~m}$ above mean sea level (msl). The two major climatic seasons in the area are the wet season from April to October and the dry season from November to March. Precipitation serves as the major source of groundwater recharge and is about $3000 \mathrm{~mm}$ annually.

The deposits of the recent Niger Delta consists of the modern and Holocene delta top deposits. These sediments are made up of medium to coarse-grained sands, sandy clays, silts and clays and constitute the shallow unconfined aquifer which is been exploited. This shallow aquifer is the primary source of water supply for many semi-urban and urban communities in the area and in the Niger Delta region in general (Amajor, 1991). The geology of the Niger Delta consists of various types of quaternary deposits underlain by the Benin, Agbada and Akata Formations (Short and Stauble, 1967; Wright et al., 1985; Kogbe, 1989). Osakuni and Abam (2004) reported that the quaternary sediments are largely alluvial and hydromorphic soils and lacustrine sediments of Pleistocene age. The Benin Formation is fluvial in origin and consists of unconsolidated sand intercalated with clay in places. The Benin Formation ranges from Miocene to Recent in age. The older and underlying Agbada Formation which serves as the hydrocarbon reservoir in the Niger Delta consists of paralic sands and shales. The basal lithostratigraphic unit is the Akata Formation and consists of marine shales which is the main source rock Formation in the Niger Delta Area.
Water table in the study area is about 3-4 m during the dry season, but during the rainy season, the water table rises considerably, in most cases, to the ground surface.

\section{MATERIALS AND METHODS}

Water samples used for this study were collected from twenty-four boreholes distributed over the study area during the month of February, 2013. The water samples were collected in clean polyethylene bottles that were rinsed with 2-3 times using the groundwater to be sampled. The boreholes were pumped for about 15 min before samples were collected. We avoided sampling water that had been treated in any way. Electrical Conductivity (EC) and $\mathrm{pH}$ of the groundwater samples were determined in the field immediately after sample collection using portable field kits (Hach's CO 150 Conductivity/TDS meter and pH meter respectively).

The samples were analyzed for major cations such as $\mathrm{Na}^{+}, \mathrm{Ca}^{2+}, \mathrm{Mg}^{2+}, \mathrm{K}^{+}$and anions $\mathrm{Cl}^{-}, \mathrm{SO}_{4}{ }^{2-}, \mathrm{CO}_{3}{ }^{2-}$, $\mathrm{HCO}_{3}^{-}$. The chemical analysis was carried out using standard procedures as suggested by the American Public Health Association (APHA, 1998). The turbidimetric method was used to determine sulphate $\left(\mathrm{SO}_{4}^{2-}\right)$ concentration in the groundwater samples. This technique is based on the principle of formation of barium sulphate in the presence of (acidified $\mathrm{HCl}$ ) barium chloride. The process is enhanced in the presence of glycerol or other organic compound. The absorbance of the colloidal solution was measured against a standard on UV visible Spectrophotometer. Sodium $\left(\mathrm{Na}^{+}\right)$and potassium $\left(\mathrm{K}^{+}\right)$content was determined using flame-emission method using a flame photometer while calcium $\left(\mathrm{Ca}^{2+}\right)$, magnesium $\left(\mathrm{Mg}^{2+}\right)$, chloride $\left(\mathrm{Cl}^{-}\right)$, carbonate $\left(\mathrm{CO}_{3}{ }^{2-}\right)$ and bicarbonate $\left(\mathrm{HCO}_{3}{ }^{-}\right)$were determined using titration method. The analytical precision of the data was determined using 
the normalized inorganic charge balance, which is defined as $\left[\left(\Sigma^{+}-\Sigma^{-}\right) /\left(\Sigma^{+}+\Sigma^{-}\right)\right]$and is expressed as the fractional difference between the total cations and total anions (Hounslow, 1995). Charge balance of most samples were generally within $\pm 10 \%$.

The chemical data were analyzed using Principal Component Analysis (PCA). Prior to the analysis, the data were standardized in order to have a mean of 0 and a standard deviation of 1 using the following formula:

$$
Z_{i}=\frac{X_{i}-\bar{X}}{S}
$$

where,

$Z_{i}=$ The $i^{\text {th }}$ value of the standardized variable $Z$

$X_{i}=$ The $i^{\text {th }}$ value of the (chemical) variable $X$

$\bar{X}=$ The mean of the values of the variable $\mathrm{X}$

$S \quad=$ Its standardized deviation

It is important to note that standardization of the variables was carried out to eliminate the influence of different units of measurement on the data by making them dimensionless. Correlation coefficients of the variables were determined using the formula:

$$
r=\frac{\sum_{i}\left(X_{i}-\bar{X}\right)\left(Y_{i}-Y\right)}{\left\{\left[\sum_{i}\left(X_{i}-\bar{X}\right)^{2}\right]\left[\sum_{i}\left(Y_{i}-\bar{Y}\right)^{2}\right]\right\}^{1 / 2}}
$$

where, $X_{i}$ and $Y_{i}$ are the $i^{\text {th }}$ values of the standardized variables $X$ and $Y, \bar{X}$ and $\bar{Y}$ are their respective means. The correlation coefficients quantify the linear relationships that exist between the $X$ and $Y$ variables. We determined the percentages of eigen values since the eigen values quantify the contribution of each factor to the total variance. When the corresponding eigen value is $>1$, the contribution of that factor is considered significant (Kaiser, 1958). The factor extraction was carried out using a minimum acceptable eigen value that is greater than 1. The factor loadings were calculated by a varimax rotation technique, which gives maximization of the variance of the factor loading of the variables. This procedure results in a new rotated factor matrix in which each factor is described in terms of only those variables and interpretation much easier. The degree of closeness between the variables and a factor is measured in terms of the factor loading. Dalton and Upchurch (1978) reported that intensity of the chemical process described by each factor can be related to the factor scores. When the value is extreme negative $(<-1.0)$, it reflects areas essentially unaffected by the process and when the value is a positive score ( $>$ +1.0 ), it reflects areas most affected. When an area is affected to an average degree by the chemical process of a particular factor, the score is near-zero.
The Water Quality Index (WQI) rating was also determined in order to quantify the suitability of the water for human use. In determining groundwater quality and its suitability for domestic purposes (Tiwari and Mishra, 1985; Avvannavar and Shrihari, 2008), WQI is an important parameter. WQI gives the composite influence of water quality parameters on the overall quality of water for human use. WQI was calculated considering the standards for drinking purposes as recommended by World Health Organization (WHO) (2004). For the purpose of computing WQI, nine water quality parameters were selected. Then each of the nine parameters (TDS, $\mathrm{HCO}_{3}, \mathrm{Cl}, \mathrm{SO}_{4}, \mathrm{NO}_{3}, \mathrm{Ca}, \mathrm{Mg}, \mathrm{Na}$ and $\mathrm{K}$ ) was assigned a weight $\left(w_{i}\right)$ depending on its relative importance in determining the overall quality of water for drinking purposes.

Due to their major importance in determining the overall water quality for human use (Srinivasamoorthy et al., 2008), parameters like nitrate, total dissolved solids, chloride and sulphate were assigned a maximum weight of 5. Since bicarbonate plays an insignificant role in the water quality assessment, it was given a minimum weight of 1 . Depending on their importance in determining water quality, parameters like calcium, magnesium, sodium and potassium were assigned weight between 1 and 5. Secondly, the relative weight $\left(W_{i}\right)$ was determined using equation:

$$
W_{i}=\frac{w_{i}}{\sum_{i=1}^{n} w_{i}}
$$

where,

$W_{i}=$ The relative weight

$w_{i}=$ The weight of each parameter

$\mathrm{n} \quad=$ The number of parameters

Lastly, we determine the quality rating scale $\left(q_{i}\right)$ for each parameter by dividing its concentration in each water sample by its respective standard based on World Health Organization (WHO) (2004) guidelines and the result is multiplied by 100 :

$$
q_{i}=\left(\frac{C_{i}}{S_{i}}\right) \times 100
$$

where,

$q_{i}=$ The quality rating

$C_{i}=$ The concentration of each chemical parameter in each water sample $(\mathrm{mg} / \mathrm{L})$

$S_{i}=$ The (World Health Organization (WHO), 2004) water standard for each chemical parameter $(\mathrm{mg} / \mathrm{L})$

In determining WQI, the SI is first computed for each chemical parameter, which was then used to determine the WQI using the equation: 
Res. J. Environ. Earth Sci., 11(2): 19-28, 2019

Table 1: WQI range and water type

\begin{tabular}{ll}
\hline Range & Type of water \\
\hline$<50$ & Excellent water \\
$50-100.1$ & Good water \\
$100-200.1$ & Poor water \\
$200-300.1$ & Very poor water \\
$>300$ & Water unsuitable for drinking purposes \\
\hline
\end{tabular}

Table 2: Hydrogeochemical analysis of groundwater samples

\begin{tabular}{|c|c|c|c|c|c|c|c|c|}
\hline Sample location & $\mathrm{pH}$ & $\mathrm{EC}$ & TDS & TA & $\mathrm{TH}$ & $\mathrm{Na}^{+}$ & $\mathrm{K}^{+}$ & $\mathrm{Ca}^{2+}$ \\
\hline Agudama & 6.83 & 2120.0 & 1060.0 & 55.0 & 143.0 & 52.2 & 30.4 & 40.50 \\
\hline Akenfa Spk 1 & 6.16 & 338.0 & 169.0 & 15.0 & 48.0 & 14.2 & 6.8 & 2.40 \\
\hline Akenfa Spk 2 & 5.78 & 615.0 & 308.0 & 26.0 & 25.0 & 28.4 & 16.5 & 4.00 \\
\hline Akenfa Spk 3 & 5.87 & 472.0 & 236.0 & 16.0 & 16.0 & 14.5 & 12.0 & 6.10 \\
\hline Akenfa Spk 4 & 6.17 & 400.0 & 200.0 & 20.0 & 6.0 & 18.2 & 9.9 & 5.40 \\
\hline Akenfa $2 \mathrm{E}$ & 5.82 & 768.0 & 384.0 & 39.0 & 50.0 & 16.5 & 6.8 & 5.50 \\
\hline Akenfa 2D & 6.03 & 515.0 & 256.0 & 21.0 & 44.0 & 18.4 & 7.5 & 3.50 \\
\hline Agudama & 6.38 & 708.0 & 354.0 & 30.0 & 48.0 & 28.4 & 9.5 & 6.80 \\
\hline Agbia Spk 1 & 6.20 & 2620.0 & 1310.0 & 48.0 & 254.0 & 60.4 & 28.5 & 36.40 \\
\hline Azikoro A & 6.24 & 800.0 & 400.0 & 28.0 & 40.0 & 14.5 & 8.7 & 5.60 \\
\hline Azikoro I & 6.15 & 1036.0 & 518.0 & 24.0 & 40.0 & 29.5 & 18.4 & 6.30 \\
\hline Azikoro Ap & 5.92 & 907.0 & 454.0 & 42.0 & 57.0 & 25.5 & 15.6 & 8.50 \\
\hline Bayelsa palms & 6.16 & 696.0 & 348.0 & 42.0 & 52.0 & 12.5 & 8.2 & 4.50 \\
\hline Igbogene 1 & 5.80 & 1091.0 & 546.0 & 33.0 & 120.0 & 42.2 & 17.6 & 5.50 \\
\hline Ekeki water B & 6.31 & 418.0 & 209.0 & 30.0 & 15.0 & 12.2 & 10.5 & 6.74 \\
\hline Igbogene & 5.87 & 1324.0 & 662.0 & 60.0 & 54.0 & 41.7 & 18.4 & 12.80 \\
\hline Nedugo K & 5.87 & 1098.0 & 549.0 & 40.0 & 48.0 & 15.4 & 9.8 & 10.70 \\
\hline Ogboloma 1 & 6.00 & 440.0 & 220.0 & 39.0 & 23.5 & 15.2 & 7.4 & 4.60 \\
\hline Opolo Comrs & 6.04 & 207.0 & 104.0 & 13.0 & 14.2 & 3.8 & 2.5 & 2.90 \\
\hline Kpansia Hon & 6.34 & 2820.0 & 1410.0 & 65.0 & 265.0 & 48.7 & 15.2 & 20.90 \\
\hline Ovom-Gwe & 6.88 & 792.0 & 396.0 & 30.0 & 68.0 & 18.8 & 8.2 & 8.00 \\
\hline NDU Camp & 6.18 & 495.0 & 248.0 & 18.0 & 42.0 & 13.8 & 6.5 & 3.50 \\
\hline Tantuama & 6.19 & 409.0 & 205.0 & 32.0 & 23.0 & 17.2 & 8.3 & 5.00 \\
\hline Forcados & 6.70 & 591.0 & 296.0 & 26.0 & 24.0 & 7.8 & 12.0 & 5.70 \\
\hline Sample location & $\mathrm{Mg}^{2+}$ & $\mathrm{Fe}$ & $\mathrm{Cl}^{-}$ & $\mathrm{SO}_{4}{ }^{2-}$ & $\mathrm{NO}_{3}^{-}$ & $\mathrm{HCO}_{3}$ & $\mathrm{Na} / \mathrm{Cl}$ & WQI \\
\hline Agudama & 10.70 & 0.50 & 31.8 & 7.20 & 0.13 & 300.8 & 1.64 & 27.80 \\
\hline Akenfa Spk 1 & 0.50 & 0.02 & 2.9 & 0.50 & 0.11 & 52.5 & 4.98 & 8.20 \\
\hline Akenfa Spk 2 & 0.80 & 0.01 & 4.8 & 4.20 & 0.08 & 103.7 & 5.89 & 9.70 \\
\hline Akenfa Spk 3 & 3.50 & 0.18 & 4.6 & 1.20 & 0.08 & 84.2 & 3.15 & 8.50 \\
\hline Akenfa Spk 4 & 3.10 & 0.15 & 12.5 & 1.80 & 0.04 & 72.0 & 1.46 & 8.70 \\
\hline Akenfa $2 \mathrm{E}$ & 2.50 & 0.24 & 5.5 & 4.60 & 0.27 & 68.3 & 2.98 & 10.70 \\
\hline Akenfa 2D & 1.20 & 0.18 & 4.8 & 1.70 & 0.16 & 67.1 & 3.83 & 8.40 \\
\hline Agudama & 3.40 & 0.12 & 17.3 & 2.80 & 0.03 & 94.6 & 1.64 & 12.10 \\
\hline Agbia Spk 1 & 8.50 & 0.02 & 82.0 & 5.70 & 0.13 & 209.8 & 0.74 & 36.30 \\
\hline Azikoro A & 3.50 & 0.25 & 11.3 & 0.90 & 0.16 & 66.5 & 1.28 & 11.40 \\
\hline Azikoro I & 2.70 & 0.05 & 14.4 & 3.20 & 0.14 & 111.0 & 2.05 & 14.00 \\
\hline Azikoro Ap & 2.20 & 0.29 & 14.8 & 4.20 & 0.05 & 98.2 & 1.72 & 13.20 \\
\hline Bayelsa palms & 5.60 & 0.32 & 14.5 & 2.50 & 0.01 & 60.4 & 0.86 & 10.90 \\
\hline Igbogene 1 & 2.30 & 0.18 & 21.2 & 4.00 & 0.09 & 126.9 & 1.99 & 15.50 \\
\hline Ekeki water B & 3.46 & 0.25 & 16.0 & 0.54 & 0.09 & 59.2 & 0.76 & 8.80 \\
\hline Igbogene & 8.80 & 0.21 & 20.4 & 3.50 & 0.14 & 183.0 & 2.04 & 19.20 \\
\hline Nedugo K & 6.20 & 0.31 & 21.6 & 10.60 & 0.00 & 70.2 & 0.71 & 15.70 \\
\hline Ogboloma 1 & 2.50 & 0.38 & 11.7 & 5.50 & 0.28 & 51.9 & 1.30 & 8.70 \\
\hline Opolo Comrs & 1.60 & 0.32 & 10.3 & 2.10 & 0.20 & 11.0 & 0.37 & 5.70 \\
\hline Kpansia Hon & 6.90 & 0.18 & 39.1 & 6.50 & 0.42 & 175.7 & 1.25 & 32.70 \\
\hline Ovom-Gwe & 1.80 & 0.18 & 8.4 & 5.40 & 0.15 & 70.0 & 2.25 & 15.70 \\
\hline NDU Camp & 1.80 & 0.86 & 14.2 & 4.70 & 1.60 & 36.0 & 0.97 & 6.30 \\
\hline Tantuama & 4.50 & 0.28 & 6.9 & 2.60 & 0.05 & 81.7 & 2.49 & 6.20 \\
\hline Forcados & 4.20 & 0.20 & 5.3 & 3.30 & 0.28 & 64.7 & 1.47 & 9.60 \\
\hline
\end{tabular}

$$
\begin{aligned}
& \mathrm{SI}_{i}=W_{i} \times q_{i} \\
& \mathrm{WQI}=\Sigma \mathrm{SI}_{i}
\end{aligned}
$$

where,

$\mathrm{SI}_{i}=$ The sub-index of $i^{\text {th }}$ parameter

$q_{i}=$ The rating based on concentration of $i^{\text {th }}$ parameter

$n \quad=$ The number of parameters

The computed values range from 5.7 to 32.7 . The WQI range and type of water is shown in Table 1.

\section{RESULTS AND DISCUSSION}

The chemical composition of the groundwater samples is presented in Table 2. The suitability of the groundwater for drinking and domestic use was determined by comparing the hydrochemical parameters of the groundwater with World Health Organization (World Health Organization (WHO), 2004) standard. The results show that all major ions in all the samples are well within the standard specified for drinking and other purposes (World Health 
Res. J. Environ. Earth Sci., 11(2): 19-28, 2019

Table 3: Descriptive statistics of analyzed groundwater samples compared with standards

\begin{tabular}{|c|c|c|c|c|c|c|c|}
\hline \multirow[b]{2}{*}{ Parameters } & \multicolumn{4}{|c|}{ Range of samples } & \multicolumn{3}{|l|}{ ISI standards } \\
\hline & Min. & Max. & Mean & S.D. & Accept limit & Max. limit & WHO limit \\
\hline $\mathrm{pH}$ & 5.78 & 6.88 & 6.16 & 0.30 & $7.0-8.5$ & $6.5-9.2$ & $8.0-8.5$ \\
\hline $\mathrm{EC}$ & 338 & 2820 & 900.42 & 691.58 & - & - & - \\
\hline TDS & 104 & 1410 & 450.29 & 345.76 & 500 & 1500 & 500 \\
\hline TA & 13 & 65 & 32.50 & 14.35 & 200 & 600 & - \\
\hline $\mathrm{TH}$ & 6 & 265 & 63.57 & 67.77 & 200 & 600 & 100 \\
\hline $\mathrm{Na}^{+}$ & 7.80 & 60 & 24 & 14.76 & 50 & - & - \\
\hline $\mathrm{K}^{+}$ & 2.50 & 30.40 & 12.22 & 6.80 & - & - & - \\
\hline $\mathrm{Ca}^{2+}$ & 2.40 & 40.50 & 9.15 & 9.84 & 75 & 200 & 75 \\
\hline $\mathrm{Mg}^{2+}$ & 0.50 & 10.70 & 3.76 & 2.71 & 200 & 400 & 50 \\
\hline $\mathrm{Fe}$ & 0.01 & 0.50 & 0.23 & 0.18 & & & \\
\hline $\mathrm{Cl}^{-}$ & 2.85 & 31.85 & 10.07 & 16.60 & 200 & 1000 & 200 \\
\hline $\mathrm{SO}_{4}{ }^{2-}$ & 0.50 & 10.60 & 3.89 & 2.28 & 200 & 400 & 200 \\
\hline $\mathrm{HCO}_{3}^{-}$ & 36 & 300.80 & 96.60 & 63.30 & - & - & - \\
\hline $\mathrm{NO}_{3}^{-}$ & 0.01 & 1.60 & 0.20 & 0.31 & - & - & 50 \\
\hline
\end{tabular}

Min.: Minimum; Max.: Maximum; S.D.: Standard deviation

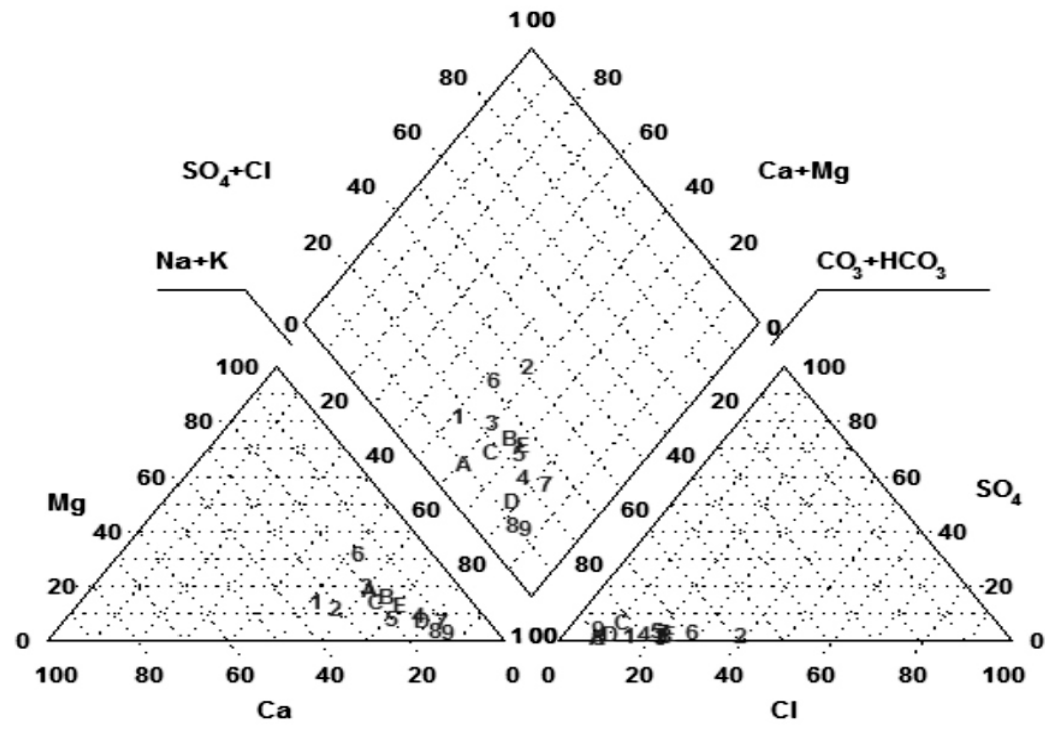

CATIONS

ANIONS
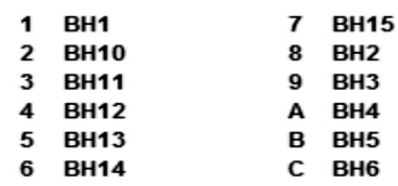

D $\mathrm{BH7}$

E BH9

Fig. 2: Chemical facies of groundwater in piper diagram

Organization (WHO), 2004), except iron were the concentrations exceed the acceptible limit in about $21 \%$ of the samples. The $\mathrm{pH}$ varied between 5.55 to 6.93 with a mean of 6.13 , an indication of mild acidity, a pattern that is common in the Niger Delta region (Amadi et al., 1989). Two key factors are responsible for the acidity in the groundwater in the Niger Delta. These are gas flaring due to oil exploration and exploitation activities by multinational oil companies and organic acids resulting from decomposition of vegetation in swampy environments (Nwankwoala and Udom, 2011; Okiongbo and Douglas, 2013). The
Electrical Conductivity (EC) in groundwater is an index of mineralisation (Hem, 1991) and its values ranged from 338 to $2820 \mu \mathrm{S} / \mathrm{cm}$ with a mean of $900 \mu \mathrm{S} / \mathrm{cm}$. The dominant anion and cation of the groundwater samples are bicarbonate and sodium. The maximum and minimum values of the analyzed parameters is given in Table 3.

On the basis of Piper Trilinear diagram (Fig. 2), $\mathrm{NaHCO}_{3}$ is the dominant water type identified in the study area. We do not have direct evidence of seawater ingress and therefore attribute the marine aerosol contribution to the soil made the infiltrating water 

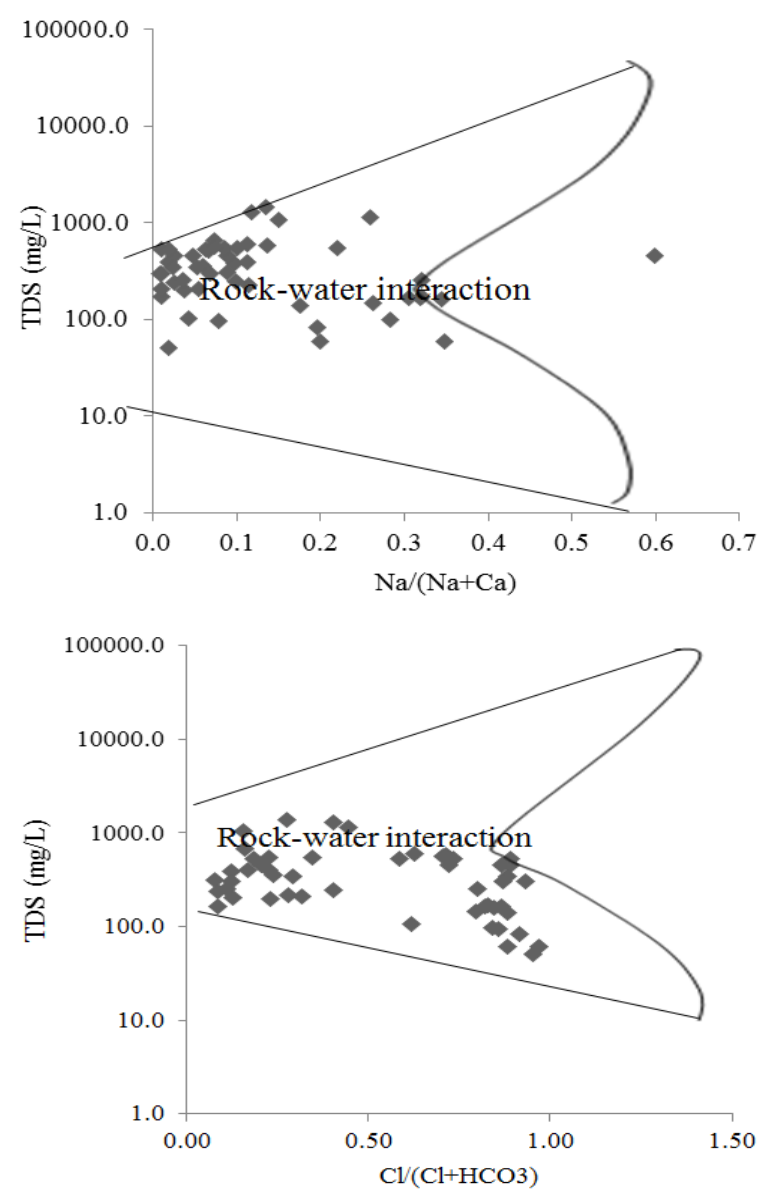

Fig. 3: Relation $\mathrm{Na} /(\mathrm{Na}+\mathrm{Ca})$ vs. TDS and between $\mathrm{Cl} /(\mathrm{Cl}$ $\left.+\mathrm{HCO}_{3}\right)$ vs. TDS diagrams indicating water-rock interaction

sodium bicarbonate type. Rock weathering processes are identified using Gibb's plot (Gibbs, 1970). The ratios of $(\mathrm{Na}+\mathrm{K}) /(\mathrm{Na}+\mathrm{K}+\mathrm{Ca})$ and $\mathrm{Cl} /\left(\mathrm{Cl}+\mathrm{HCO}_{3}\right)$ of the groundwater samples were plotted against TDS (Fig. 3). The density of the distribution of points is maximum in the centre of the Figure, indicating the influence of rock-water interaction. In the study area, fine fragments of feldspars and micas with terrigenous alternation with sands, clays and shales occur within the aquifer matrix (Amadi et al., 1989). The presence of these silicate rocks in the study area implies that the groundwater chemistry is dominated by silicate weathering (Okiongbo and Douglas, 2013). For instance, the calculated molar ratio of $\mathrm{Na} / \mathrm{Cl}$ for groundwater samples range from 0.11-9.09 (Fig. 4a). Samples having $\mathrm{Na} / \mathrm{Cl}$ ratio $>1$, imply an excess sodium. Since aquifer consists mainly of silicate materials, we opine that the sodium might have come from silicate weathering.

Rogers (1989) reported that in situations where sodium is derived from silicate weathering, the groundwater samples would have elevated concentrations of biarbonate $\left(\mathrm{HCO}_{3}{ }^{-}\right)$, hence $\mathrm{HCO}_{3}{ }^{-}$

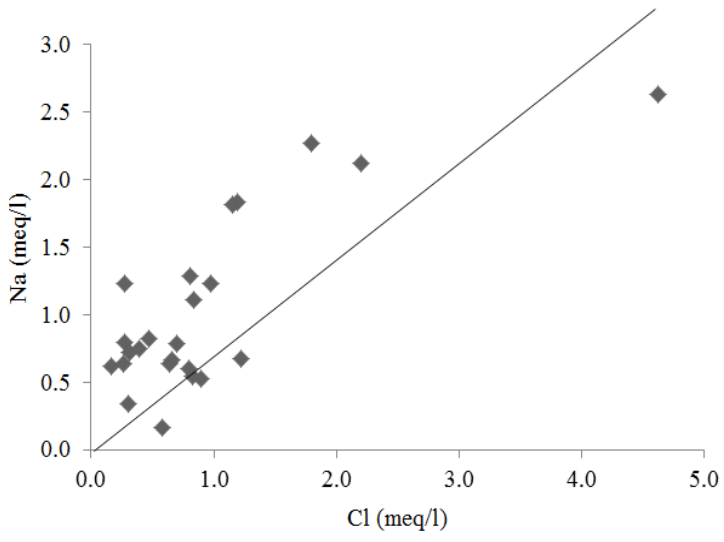

(a)

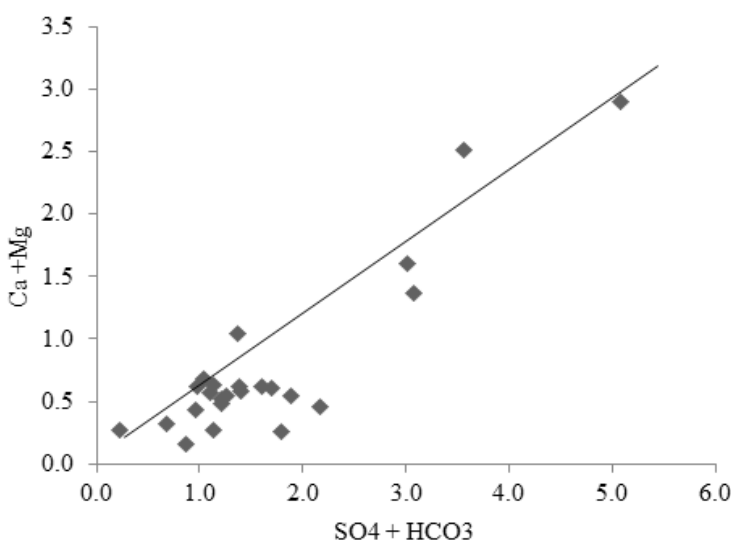

(b)

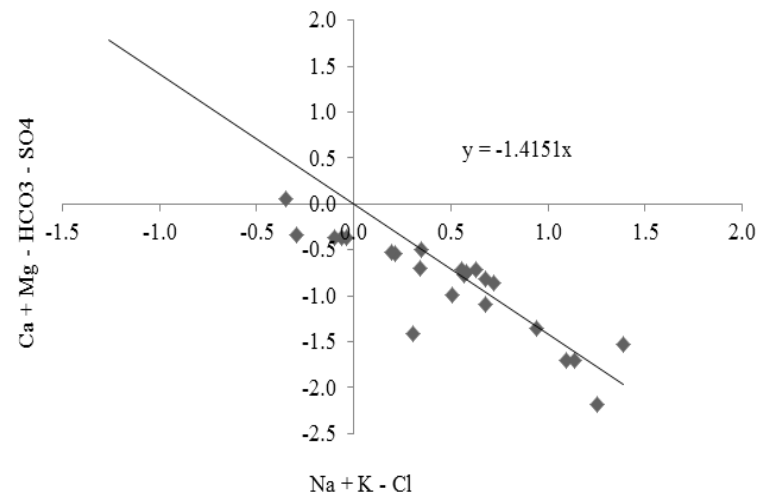

(c)

Fig. 4: (a) Relation between $\mathrm{Na}^{+}$versus $\mathrm{Cl}^{-}$in the groundwater in the study area (b) $\mathrm{Ca}+\mathrm{Mg}$ versus $\mathrm{HCO}_{3}+\mathrm{SO}_{4}$ scatter diagram (c) Graph of $\mathrm{Ca}+\mathrm{Mg}$ $\mathrm{HCO}_{3}-\mathrm{SO}_{4}$ versus $\mathrm{N} \mathrm{a}+\mathrm{K}-\mathrm{Cl}$ of the samples in the study area

would be the most abundant anion. Elango et al. (2003) observed that the reaction between feldspar minerals with carbonic acid in the presence of water releases $\mathrm{HCO}_{3}{ }^{-}$. In Table $2, \mathrm{HCO}_{3}{ }^{-}$is the dominant anion in the 
Res. J. Environ. Earth Sci., 11(2): 19-28, 2019

Table 4: Correlation coefficient matrix of analyzed ions

\begin{tabular}{|c|c|c|c|c|c|c|c|}
\hline Sample & $\mathrm{pH}$ & EC & TDS & TA & $\mathrm{TH}$ & $\mathrm{Na}^{+}$ & $\mathrm{K}^{+}$ \\
\hline$\overline{\mathrm{pH}}$ & 1.000 & & & & & & \\
\hline $\mathrm{EC}$ & 0.055 & 1.000 & & & & & \\
\hline TDS & 0.055 & 1.000 & 1.000 & & & & \\
\hline TA & 0.010 & 0.643 & 0.643 & 1.000 & & & \\
\hline TH & 0.052 & 0.885 & 0.885 & 0.459 & 1.000 & & \\
\hline $\mathrm{Na}^{+}$ & 0.010 & 0.766 & 0.766 & 0.487 & 0.680 & 1.000 & \\
\hline $\mathrm{K}^{+}$ & 0.029 & 0.587 & 0.587 & 0.335 & 0.406 & 0.780 & 1.000 \\
\hline $\mathrm{Ca}^{2+}$ & 0.151 & 0.753 & 0.753 & 0.449 & 0.409 & 0.656 & 0.702 \\
\hline $\mathrm{Mg}^{2+}$ & 0.077 & 0.572 & 0.572 & 0.627 & 0.338 & 0.417 & 0.466 \\
\hline $\mathrm{Fe}$ & 0.015 & -0.006 & -0.006 & 0.004 & -0.011 & -0.040 & -0.026 \\
\hline $\mathrm{Cl}^{-}$ & 0.017 & 0.728 & 0.728 & 0.352 & 0.738 & 0.625 & 0.487 \\
\hline $\mathrm{SO}_{4}{ }^{2-}$ & 0.012 & 0.276 & 0.277 & 0.308 & 0.183 & 0.145 & 0.128 \\
\hline $\mathrm{NO}_{3}{ }^{-}$ & 0.006 & 0.000 & 0.000 & -0.017 & 0.001 & -0.013 & -0.035 \\
\hline $\mathrm{HCO}_{3}{ }^{-}$ & 0.063 & 0.699 & 0.699 & 0.521 & 0.497 & 0.837 & 0.855 \\
\hline Sample & $\mathrm{Ca}^{2+}$ & $\mathrm{Mg}^{2+}$ & $\mathrm{Fe}$ & $\mathrm{Cl}^{-}$ & $\mathrm{SO}_{4}^{2-}$ & $\mathrm{NO}_{3}{ }^{-}$ & $\mathrm{HCO}_{3}$ \\
\hline
\end{tabular}

\begin{tabular}{|c|c|c|c|c|c|c|c|}
\hline \\
\hline $\begin{array}{l}\mathrm{pH} \\
\mathrm{EC}\end{array}$ & & & & & & & \\
\hline \multicolumn{8}{|l|}{ TDS } \\
\hline \multicolumn{8}{|l|}{ TA } \\
\hline \multicolumn{8}{|l|}{ TH } \\
\hline \multicolumn{8}{|l|}{$\mathrm{Na}^{+}$} \\
\hline \multicolumn{8}{|l|}{$\mathrm{K}^{+}$} \\
\hline $\mathrm{Ca}^{2+}$ & 1.000 & & & & & & \\
\hline $\mathrm{Mg}^{2+}$ & 0.681 & 1.000 & & & & & \\
\hline $\mathrm{Fe}$ & 0.001 & 0.016 & 1.000 & & & & \\
\hline $\mathrm{Cl}^{-}$ & 0.677 & 0.453 & -0.005 & 1.000 & & & \\
\hline $\mathrm{SO}_{4}{ }^{2-}$ & 0.256 & 0.199 & 0.067 & 0.186 & 1.000 & & \\
\hline $\mathrm{NO}_{3}^{-}$ & -0.006 & -0.021 & 0.516 & 0.000 & 0.013 & 1.000 & \\
\hline $\mathrm{HCO}_{3}{ }^{-}$ & 0.803 & 0.633 & 0.008 & 0.437 & 0.175 & 0.027 & 1.000 \\
\hline
\end{tabular}

groundwater, suggesting that $\mathrm{Na}^{+}$in the groundwater was derived from silicate weathering. Samples with a $\mathrm{Na} / \mathrm{Cl}$ ratio around 1 or $<1$ indicate the possibility of some other chemical processes in the groundwater such as ion exchange (Elango et al., 2003).

To further evaluate and interpret the possibility that the process of ion exchange is significant within the aquifer system, the graph of $\mathrm{Ca}^{2+}+\mathrm{Mg}^{2+}$ vs. $\mathrm{SO}_{4}+$ $\mathrm{HCO}_{3}{ }^{-}$was used as a major indicator to determine the ion exchange process (Cerling et al., 1989; Fisher and Mulican, 1997). Cerling et al. (1989) and Fisher and Mulican (1997) observed that if ion exchange is a significant process within the aquifer, in the graph of $\mathrm{Ca}^{2+}+\mathrm{Mg}^{2+}$ vs. $\mathrm{SO}_{4}+\mathrm{HCO}_{3}^{-}$the points would shift to the right side of the graph due to an excess of $\mathrm{SO}_{4}+$ $\mathrm{HCO}_{3}{ }^{-}$. On the otherhand, if reverse ions exchange is the process, then data points would shift to the left side due to abundance of $\mathrm{Ca}+\mathrm{Mg}$ over $\mathrm{SO}_{4}+\mathrm{HCO}_{3}{ }^{-}$. The graph of $\mathrm{Ca}^{2+}+\mathrm{Mg}^{2+}$ vs. $\mathrm{SO}_{4}+\mathrm{HCO}_{3}{ }^{-}$(Fig. 4b) shows that most of the groundwater samples cluster around and below the 1:1 line, indicating ion exchange process is significant (El-Sayed et al., 2012). Also, the graph of $\mathrm{Ca}^{2+}+\mathrm{Mg}^{2+}-\mathrm{HCO}_{3}-\mathrm{SO}_{4}$ against $\mathrm{Na}^{+}+\mathrm{K}^{+}-\mathrm{Cl}^{-}$gives evidence of cation exchange (Fig. 4c). McLean et al. (2000) observed that in a graph of $\mathrm{Ca}^{2+}+\mathrm{Mg}^{2+}-\mathrm{HCO}_{3}$ - $\mathrm{SO}_{4}$ against $\mathrm{Na}^{+}+\mathrm{K}^{+}-\mathrm{Cl}^{-}$, if cation exchange process is not a significant reaction in the aquifer system, all data points would plot close to the origin. But if cation exchange is significant and was an important composition controlling process, the relation between $\mathrm{Ca}^{2+}+\mathrm{Mg}^{2+}-\mathrm{HCO}_{3}-\mathrm{SO}_{4}$ and $\mathrm{Na}^{+}+\mathrm{K}^{+}-\mathrm{Cl}^{-}$ whould be linear with a slope of -1 . Figure $4 \mathrm{c}$ shows an increase in $\mathrm{Na}^{+}+\mathrm{K}^{+}$related to a decrease in $\mathrm{Ca}^{2+}+$ $\mathrm{Mg}^{2+}$ or an increase in $\mathrm{HCO}_{3}+\mathrm{SO}_{4}$. All the data points plot close to the straight line with a slope of -1.4, implying that some of the $\mathrm{Na}^{+}, \mathrm{Ca}^{2+}$ and $\mathrm{Mg}^{2+}$ participate in the ion exchange reaction process (Garcia et al., 2001).

Bicarbonate content of the groundwater samples vary from 11-300 mg/L with a mean value of 96.6 $\mathrm{mg} / \mathrm{L}$. Carbon dioxide given off by plant roots and decaying organic matter adds to the bicarbonate content when dissolved in the soil water. Hence, high $\mathrm{HCO}_{3}$ content of this area may also be due to dissolution of soil $\mathrm{CO}_{2}$. In the study area, the water table is about 3-4 $\mathrm{m}$, the sediments are pyritic carbonaceous (peat, lignite and organic matter) wetland deposits. Inorganic sulphides including iron pyrite and other iron bearing minerals such as pyroxene, amphibioles, biotite, magnetite and olivine are in these sediments (Amajor, 1991). The presence of organic material acts to promote development of reducing (low oxygen) geochemical conditions which causes reduction of iron pyrite which in turn results in high dissolved iron concentrations in groundwater in this aquifer (Aris et al., 2007).

Statistical analysis was carried out to determine the correlation coefficient to indicate the sufficiency of one variable to predict the other (Davis, 1986). Using factor analysis, the principal factor from the sources of variation in the hydrochemistry was extracted. Using varimax rotation, factor scores and percentage of variance in the hydrochemistry was defined (Kaiser, 1958). When the correlation coefficient is high, the relationship between two variables is considered 
Table 5: Results of principal component analysis with Varimax rotation

\begin{tabular}{|c|c|c|c|}
\hline \multirow[b]{2}{*}{ Chemical variables } & \multicolumn{3}{|c|}{ Principal components } \\
\hline & I & II & III \\
\hline $\mathrm{pH}$ & 0.253 & 0.238 & -0.885 \\
\hline $\mathrm{EC}$ & 0.969 & 0.023 & 0.079 \\
\hline TDS & 0.969 & 0.024 & 0.080 \\
\hline TA & 0.814 & 0.058 & 0.146 \\
\hline $\mathrm{TH}$ & 0.883 & 0.033 & 0.115 \\
\hline $\mathrm{Na}^{+}$ & 0.918 & -0.154 & 0.118 \\
\hline $\mathrm{K}^{+}$ & 0.857 & -0.185 & -0.077 \\
\hline $\mathrm{Ca}^{2+}$ & 0.936 & 0.063 & -0.201 \\
\hline $\mathrm{Mg}^{2+}$ & 0.829 & 0.084 & -0.166 \\
\hline $\mathrm{Fe}$ & -0.077 & 0.928 & -0.015 \\
\hline $\mathrm{Cl}^{-}$ & 0.857 & 0.007 & 0.112 \\
\hline $\mathrm{SO}_{4}{ }^{2-}$ & 0.577 & 0.382 & 0.282 \\
\hline $\mathrm{NO}^{3-}$ & -0.086 & 0.867 & 0.137 \\
\hline $\mathrm{HCO}_{3}^{-}$ & 0.920 & -0.100 & -0.127 \\
\hline Eigenvalues & 8.450 & 1.900 & 1.045 \\
\hline $\begin{array}{l}\text { (\%) of variance explained } \\
\text { by component }\end{array}$ & 60.353 & 13.575 & 7.466 \\
\hline Cumulative $\%$ of variance & 60.353 & 73.928 & 81.394 \\
\hline
\end{tabular}

significant and a zero correlation coefficient means no relationship. When the values of $r$ are positive, the relationship is positive while an inverse relationship exists when $r$ values are negative. Table 4 shows the correlation coefficient matrix of analyzed ions. Table 4 shows that EC of groundwater and the major components of seawater $\left(\mathrm{Na}^{+}\right.$and $\left.\mathrm{Cl}^{-}\right)$showed significant correlation $\left(\mathrm{EC}-\mathrm{Na}^{+}, \mathrm{r}=0.766, \mathrm{EC}-\mathrm{Cl}^{-}\right.$, $\mathrm{r}=0.728$ with; $\mathrm{p}<0.01$ ), also, chloride significantly correlated with sodium $(\mathrm{r}=0.625, \mathrm{p}<0.01)$ and calcium $(\mathrm{r}=0.677, \mathrm{p}=<0.01)$, an indication of seawater influence on the groundwater quality. But the results of hydro-geochemical analysis do not support direct seawater ingress though the groundwater samples have marine signatures. We attribute the saline signature to the effect of marine aerosol (Aris et al., 2007).

A three factor model was extracted that explained over $80 \%$ of the total groundwater quality variation (Table 5). From the computed data, three factors explaining $81.394 \%$ of the variance in the data were obtained and rotated according to the orthogonal Varimax method and their respective loadings are presented in Table 5. Factor 1 accounted for $60.35 \%$ of the total variance in the data set and was characterized by the association EC, TDS, TA, TH, Na, $\mathrm{K}^{+}, \mathrm{Ca}^{2+}$, $\mathrm{Mg}^{2+}, \mathrm{Cl}^{-}$and $\mathrm{HCO}_{3}$. This factor reflects the signatures of natural recharge and water-soil/rock interaction. For instance, the high positive loadings of $\mathrm{Na}^{+}$and $\mathrm{K}^{+}$ions is as a result of natural weathering of rock minerals and various ion-exchange processes that occur in the groundwater system. This is corroborated by the strong loading of $\mathrm{HCO}_{3}{ }^{-}$ions with alkali and alkaline earth metals (Srivastava and Ramanathan, 2008). We attribute the high positive loading of $\mathrm{HCO}_{3}{ }^{-}$is to the reaction of feldspar minerals with carbonic acid in the presence of water (Elango et al., 2003). Factor 2, explains $13.58 \%$ of the total variance with high loadings on $\mathrm{Fe}$ and $\mathrm{NO}_{3}$. The high positive loadings on the second principal component observed on the iron concentrations (Table 4), are inferred to be due to the reduction of iron pyrite and dissolution of iron bearing minerals under anaerobic and low $\mathrm{pH}$ conditions. These conditions exist where the decomposition of organic matter consumes oxygen and generates acids such as organic rich sediments, leaky sewers, septic systems and wastewater disposal systems (Chirenje et al., 2007).

In the study area, nitrate has no significant lithologic source and thus must be associated with anthropogenic activities. Factor 3 explained $10.95 \%$ of the total variance and is found to be associated with strong negative loading of $\mathrm{SO}_{4}{ }^{2-}$ and weak $\mathrm{pH}$. This factor may be attributed to anthropogenic activities such as domestic waste discharge. Table 2 shows the classification of water using the WQI values. The water quality index values of the study area range from 5.732.7. The WQI model takes into account a group of water quality parameters and is considered to be more accurate and representative of the groundwater quality in the study area. According to the WQI classification, all the samples indicate excellent water quality.

\section{CONCLUSION}

The hydrochemical nature of the groundwater in Yenagoa and environs was studied using 24 groundwater samples collected from domestic boreholes and analyzed to investigate the suitability of the groundwater for domestic use. In general, major anions and cations are well below WHO prescribed limits for drinking water except iron. Prevalent water type in the study area is $\mathrm{Na}-\mathrm{HCO}_{3} . \mathrm{EC}, \mathrm{Na}^{+}$and $\mathrm{Cl}^{-}$ showed significant correlation, an indication of seawater influence on the groundwater quality. We attribute the saline signature to the effect of marine aerosol since there was no evidence of direct seawater ingress. Rock-water interaction, reduction of inorganic sulphides including iron pyrite, weathering of silicates are significant processes that strongly influence the chemical composition of the groundwater in the study area.

Also, the weathering of silicate minerals controls the major ion chemistry of sodium, potassium, calcium and magnesium. In the study area, nitrate and chloride do not have significant lithologic source and thus must be associated with the anthropogenic activities such as sewage wastes. The Water Quality Index (WQI) of the study area ranged between 6.2-36.3 and based on WQI classification, all the samples indicate excellent water quality.

\section{ACKNOWLEDGMENT}

The authors are grateful to all home owners who allowed us access to their premises to collect water 
samples from their domestic boreholes. Special thanks to $\mathrm{Mr}$ Suoye Diete-Spiff of the Central Research Laboratory, Niger Delta University for the physicochemical analysis.

\section{CONFLICT OF INTEREST}

We have no conflict of interest.

\section{REFERENCES}

Al-Taani, A.A., 2012. Seasonal variations in water quality of Al-Wehda Dam north of Jordan and water suitability for irrigation in summer. Arab. J. Geosci., 6: 1131-1140.

Amadi, P.A., C.O. Ofoegbu and T. Morrison, 1989. Hydrogeochemical assessment of groundwater quality in parts of the Niger Delta, Nigeria. Environ. Geol. Water Sci., 14(03): 195-202.

Amajor, L.C., 1991. Aquifers in the Benin formation (Miocene-Recent), Eastern Niger Delta, Nigeria: Lithostratigraphy, Hydraulics, and water quality. Environ. Geol. Water Sci., 17: 85-101.

Andre, L., M. Franceschi, P. Pouchan and O. Atteia, 2005. Using geochemical data and modelling to enhance the understanding of groundwater flow in a regional deep aquifer, Aquitaine Basin, southwest of France. J. Hydrol., 305(1-4): 40-62.

APHA, 1998. Standard Methods for the Examination of Water and Wastewater. 19th Edn., American Public Health Association, Washington DC, USASS.

Aris, A.Z., M.H. Abdullah, A. Ahmed and K.K. Woong 2007. Controlling factors of groundwater hydrochemistry in a small island's aquifer. Int. J. Environ. Sci. Tech., 4(4): 441-450.

Avvannavar, S.M. and S. Shrihari, 2008. Evaluation of water quality index for drinking purposes for river Netravathi, Mangalore, South India. Environ. Monit. Assess., 143: 279-290.

Cerling, T.E., B.L. Pederson and K.L.V. Damm, 1989. Sodium-Calcium ion exchange in the weathering of shales: Implications for global weathering budgets. Geology, 17: 552-554.

Chirenje, T., C. Epstein and R. Mueller, 2007. Water Quality Issues in the Outer Coastal Plains: New Jersy. In: Sarkar, D., R. Datta and R. Hannigan (Eds.): Developments in Environmental Science. Elsevier Ltd., Amsterdam, The Netherlands, pp: 561-589.

Dalton, M.G. and S.B. Upchurch, 1978. Interpretation of hydrochemical facies by factor analysis. Groundwater, 16(4): 228-233.

Davis, J.C., 1986. Statistics and Data Analysis in Geology. 2nd Edn., John Willey and Sons, New York.
Elango, L., R. Rannan and K.M. Senthil, 2003. Major ion chemistry and identification of hydrogeochemical processes of groundwater in a part of Kancheepuram District, Tamil Nadu, India. J. Environ. Geosci., 10: 157-166.

El Kashony, M., A.A. Aziz, M. Soliman and H. Mesbah, 2012. Hydrogeophysical investigation of groundwater potential in the El Bawiti, Northern Bahariya Oasis, Western Desert, Egypt. Arab J. Geosci., 5: 953-970.

El-Sayed, M.H., M.M. Abo El-Fadl and H.A. Shawky, 2012. Impact of hydrochemical processes on groundwater quality, Wadi Feiran, South Sinai, Egypt. Australian J. Basic Appl. Sci., 6(3): 638-654.

Fisher, R.S. and W.F. Mulican, 1997. Hydrochemical evolution of sodium-sulfate and sodium-chloride groundwater beneath the Northern Chihuahuan desert, Trans-Pecos, Rexas, USA. Hydrogeol. J., 5(2): 1-6.

Garcia, M.G., M. del v Hildalgo and M.A. Blesa, 2001. Geochemistry of groundwater in the alluvial plain of Tucuman province, Argentina. Hydrogeol. J., 9: 597-610.

Gibbs, R.J., 1970. Mechanisms controlling world water chemistry. Science, 170(3962): 1088-1090.

Hem, J.D., 1991. Study and Interpretation of the Chemical Characteristics of Natural Water. 3rd Edn., US Geological Survey Water-Supply Paper 2254, pp: 264.

Hounslow, A.W., 1995. Water Quality Data Analysis and Interpretation. Lewis Publisher, New York, pp: 397.

Kaiser, H.F., 1958. The varimax criterion for analytic rotation in factor analysis. Pschometrika, 23: 187-200.

Ketara, M., M. Gueddari and R. Bouhlila, 2012. Use of geographical information system and water quality index to assess groundwater quality in El Khairat deep aquifer (Enfidha, Central East Tunisia). Arab. J. Geosci., 5: 1379-1390.

Kogbe, C.A., 1989. The Cretaceous and Paleogene Sediments of Southern Nigeria. Geology of Nigeria 2nd Edn., Rock View (Nig) Ltd., pp: 325-334.

McLean, W., J. Jankowski and N. Levitt, 2000. Groundwater Quality and Sustainability in an Alluvial Aquifer, Australia. In: Sililo, O. (Ed.), Groundwater, Past Achievements and Future Chanllenges. Rotterdam, Balkenna, pp: 567-573.

Nwankwoala, H.O. and G.J. Udom, 2011. Hydrogeochemical evaluation of groundwater in parts of Eastern Niger Delta, Nigeria. J. Acad. Appl. Stud., 1: 33-58.

Okiongbo, K.S. and R.K. Douglas, 2013. Hydrogeochemical analysis and evaluation of groundwater quality In Yenagoa City and environs, Southern Nigeria. Ife J. Sci., 15: 209-222. 
Osakuni, M.U. and T.K.S. Abam, 2004. Shallow resistivity measurement for cathodic protection of pipelines in the Niger Delta. Environ. Geol., 45(06): 747-752.

Rogers, R.J., 1989. Geochemical comparison of ground water in areas of New England, New York, and Pennsylvania. Groundwater, 27(5): 690-712.

Saji Kumar, P.J., P. Jegathambai and E.J. James, 2011. Multivariate and geostatistical analysis of groundwater quality in Palar river basin. Int. J. Geol., 5: 108-119.

Sanchez, E., M.F. Colmenarejo, J. Vicente, A. Rubio, M.G. Garcia, L. Travieso and R. Borja, 2007. Use of the water quality index and dissolved oxygen deficit as simple indicators of watersheds pollution. Ecol. Indicat., 7(02): 315-328.

Short, K.C. and A.J. Stauble, 1967. Outline of geology of Niger Delta. AAPG Bull., 51(05): 761-779.

Singh, V. and U.C. Singh, 2008. Assessment of groundwater quality of parts of Gwalior (India) for agricultural purposes. Indian J. Sci. Technol., 1: $1-5$.
Srinivasamoorthy, K., S. Chidambaram, M.V. Prasanna, M. Vasanthavihar, J. Peter and P. Anandhan, 2008. Identification of major sources controlling groundwater chemistry from a hard rock terrain-A case study from Mettur taluk, Salem district, Tamil Nadu, India. J. Earth Syst. Sci., 117: 49-58.

Srivastava, S.K. and A.L. Ramanathan, 2008. Geochemical assessment of groundwater quality in vicinity of Bhalswa landfill, Delhi, India, using graphical and multivariate statistical methods. Environ. Geol., 53(07): 1509-1528.

Tiwari, T.N. and M.A. Mishra, 1985. A preliminary assignment of water quality index of major Indian rivers. Indian J. Environ. Protect., 5: 276-279.

World Health Organization (WHO), 2004. Guidelines for Drinking Water Quality Incorporating. 1st and 2nd Vol. 1 Recommendations 3rd Edn., Geneva.

Wright, J.B., D.A. Hasting, W.B. Jones and H.R. Williams, 1985. Geology and Mineral Resources of West Africa. Allen and Unwin Ltd., UK, pp: 107. 